\title{
QUANTITATIVE AND QUALITATIVE EVIDENCE OF ANTHROPOGENIC FINGERPRINT IN FLOODING IN TARABA STATE OF NIGERIA
}

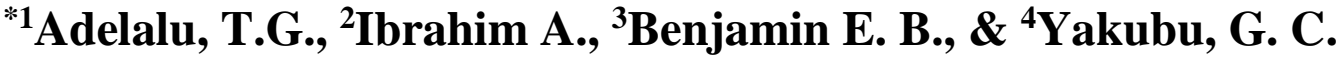

\author{
${ }^{*}, 2 \& 3$ Department of Geography, Taraba State University (TSU), Jalingo, Taraba State, Nigeria \\ ${ }^{4}$ Department of Geography College of Education (COE), Zing, Taraba State, Nigeria \\ Corresponding Author Phone: 08060555699 Email: topeadelalu@gmail.com
}

\begin{abstract}
Anthropogenic nexus of environmental change is a vital issue in flood control and hazard management. While it is true that some will loom in flood and others in drought, it is no longer valid to argue the authenticity of climate change. Though climate change alters our physical veracities, the problem of yearly flooding is more a human than a natural one in Taraba State. This paper provides technical proof of anthropogenic impression in the incessant flooding in the area. Both spatial and hydro-climatic data were used for this study in addition to designed questionnaire. Hydro and climatic data were collected from Upper Benue River Basin Development Agency, Yola. Correlation matrix was used to show the extent of climatic variation and GIS depicts the land use change. Rainfall has not related well with excess channel flow. Coefficient of variation in rainfall and runoff is not pronounced. R- Factor in all the gauging stations is very low. Built up area occupied just $2.8 \%$ of the area accounting for 806.9 hectares. Cultivated area and the bare land was about 13146.2 hectares. This accounts for about $46.3 \%$ of the area. Vegetation cover occupied more than half of the study area. This accounts for $50.1 \%$ of the land mass of the catchment area under study. Owing to the occurrence of good vegetation cover, which is more than $50 \%$ of the basin area, generally one would have expected low occurrence of flooding in the study area. The farmers' assessment agreed with the scientific analysis. The runoff volumes that traverse the state three decades ago without much disturbance now pose a serious ache. Though Inter catchment link and discharge thereof is a factor, the cogwheel pinpoints land use change and encroachment of floodplain. Parastatals involved in the land survey and planning of the state should wake up to the challenge.
\end{abstract}

Keywords: Anthropogenic, Climate change, Encroachment, Flood, and Land use change

LICENSE: This work by Open Journals Nigeria is licensed and published under the Creative Commons Attribution License 4.0 International License, which permits unrestricted use, distribution, and reproduction in any medium, provided this article is duly cited.

COPYRIGHT: The Author(s) completely retain the copyright of this published article.

OPEN ACCESS: The Author(s) approves that this article remains permanently online in the open access (OA) mode.

QA: This Article is published in line with "COPE (Committee on Publication Ethics) and PIE (Publication Integrity \& Ethics)". 


\section{INTRODUCTION}

Anthropogenic activities have been reported as major causes of climate change. Human activities since the industrial revolution have increased the atmospheric concentration of various greenhouse gasses, leading to increased air pollution from $\mathrm{CO}_{2}$, methane, troposphere ozone, CFCs and nitrous oxide. Predrag and Slobodan, 2007, had long asserted that changes in the earth's climatic system can disrupt the delicate balance of the hydrologic cycle and can eventually lead to increased occurrence of extreme events (such as floods, droughts, heat waves, summer and ice storms. In the same vein, increase in population growth and the resultant rise in the need for food production. Researchers (McKenzie and Williams, 2015; Parvin, et al., 2019) agreed that aggressive anthropogenic activities greatly influence land use and land cover and consequently climate change.

Taraba state is an agrarian community. The state is endowed with natural resources; vast lands, water resources, animal resources and human resources (Adelalu et al.2020b). More than 70 percent of the inhabitants derive their livelihood directly or indirectly from agriculture or agricultural related business. In the face of climate change, the means of livelihood of the inhabitants who are mostly farmers has dwindled (Adelalu et al.2020a). Climate change has begun to create havoc in the state (Oruonye, 2012a). The increased adverse impact of the flood is expected on the physical infrastructure, human health, natural resources, economic activities, and the environment (Plate I-V). This can be compounded with the increase in the deforestation, general burning in the farming season, overgrazing and the recent mass lumbering business of rose wood in the southern part of the state. IMF (1993) asserted that poverty and the environment are linked because the poor in the community are more likely to resort to activities that can degrade the environment. More lands could be denuded and resultant runoff could lead to flooding.

Since its creation in 1991, Taraba state has experienced several socio-economic and natural of which rural farmers are the most vulnerable. The vulnerability surges in the face of the incessant crisis in the region. Flooding is next to religious and tribal crisis in the context of economic back pedaling of the government effort to curb poverty in the state. Amidst plenty, food insecurity and incessant crisis ravage the government efforts to sustainable agricultural and economic development. The current COVID-19 pandemic may reduce the government's responsiveness and commitment to the nationwide effective monitoring, adaptation and mitigation measures to climate change in the country.

Previous studies on the flooding issue in the state concentrated on the farmers perception and adaptation to climate change (Adebayo and Orunoye, 2013), awareness of the effect of climate change among students of tertiary institution in Jalingo (Oruonye, 2011), Land use and its implication on natural environment of Donga (Adelalu and Zemba, 2017).To provide comprehensive flood control/prevention plans or policies particularly in areas prone to floods, there is need for state wide study that analyze the interaction between climatic factors and the runoff. New instruments, techniques and methods have been developed to capture rainfall and hydrological processes at high resolution (Elena et al., 2017). Quantitative and qualitative device to investigate the physical environment influence on the functioning and development of societies are no longer wanting. A quantitative and qualitative knowledge of the spatio-temporal changes in rainfall and temperature and the resultant river flows is crucial in the study area. This informs the government on the right policy direction and approaches to be pursued. This is particularly important to 
help in modeling and designing effective adaptation strategies to cope with the potential impacts of this incessant flooding.

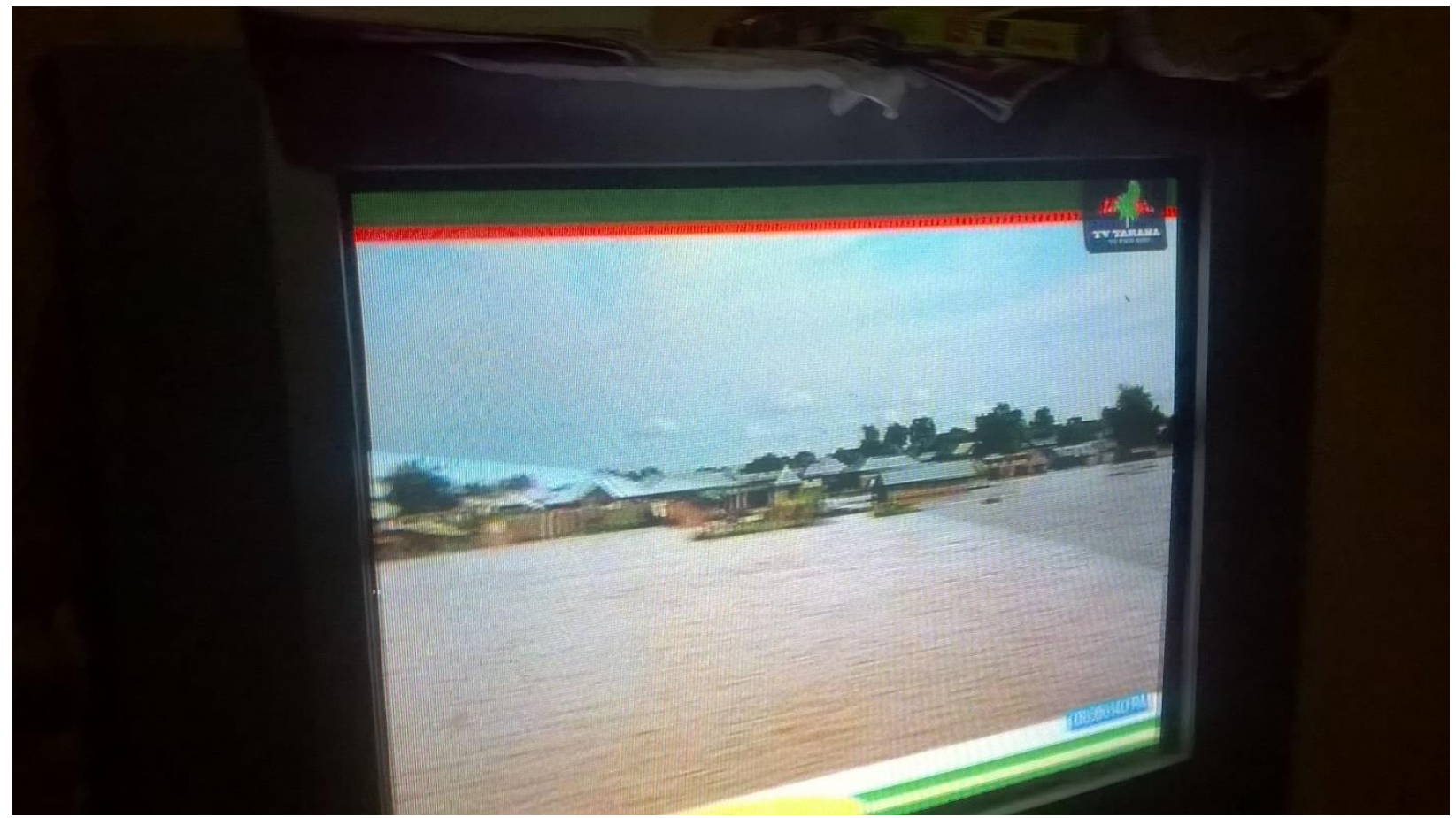

Plate 1: Taraba TV News channel displaying flood hijacked school in Ibi

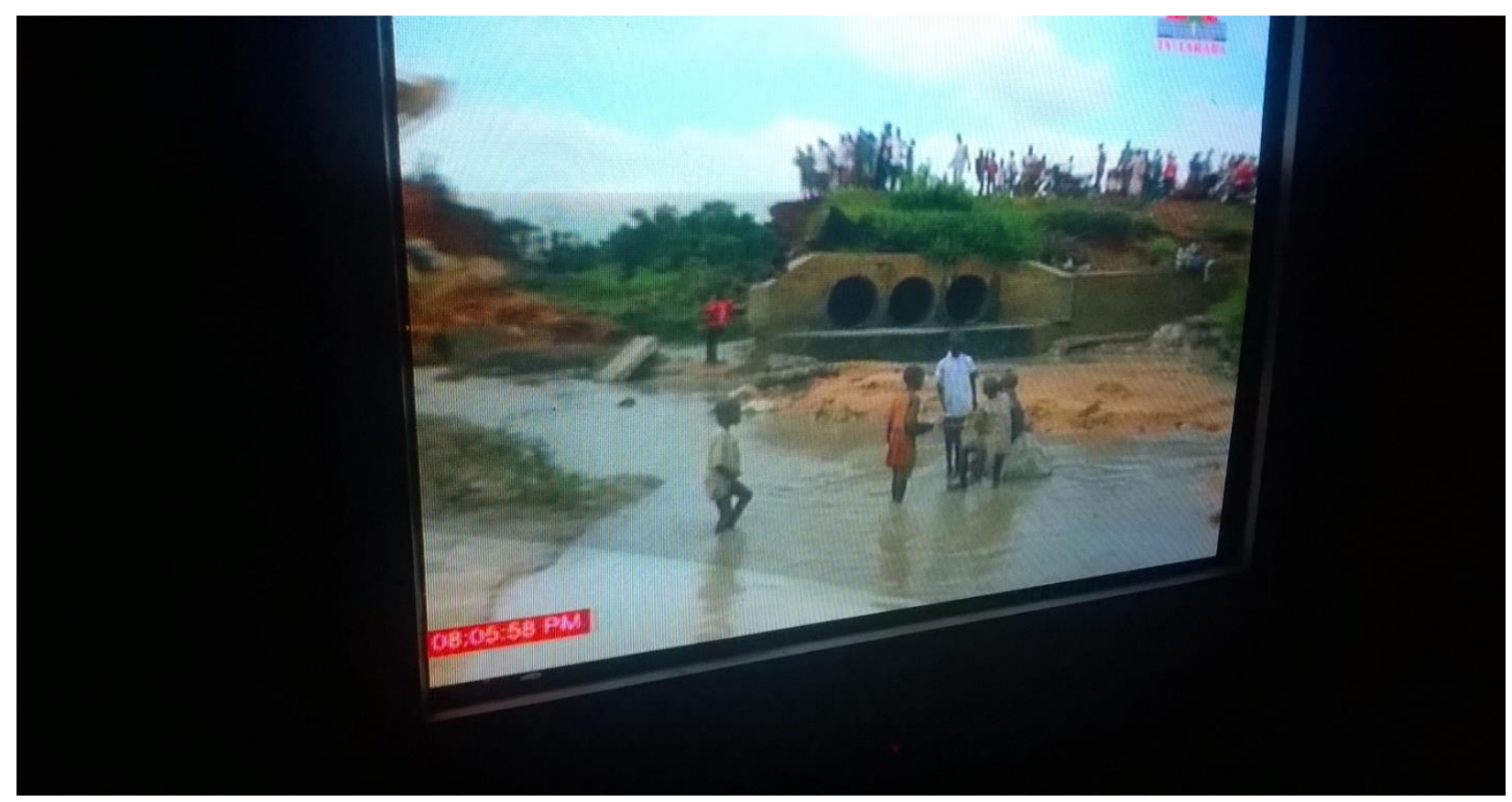

Plate 2: Taraba TV News channel displaying collapsed bridge at Maraban Gassol due to flooding 


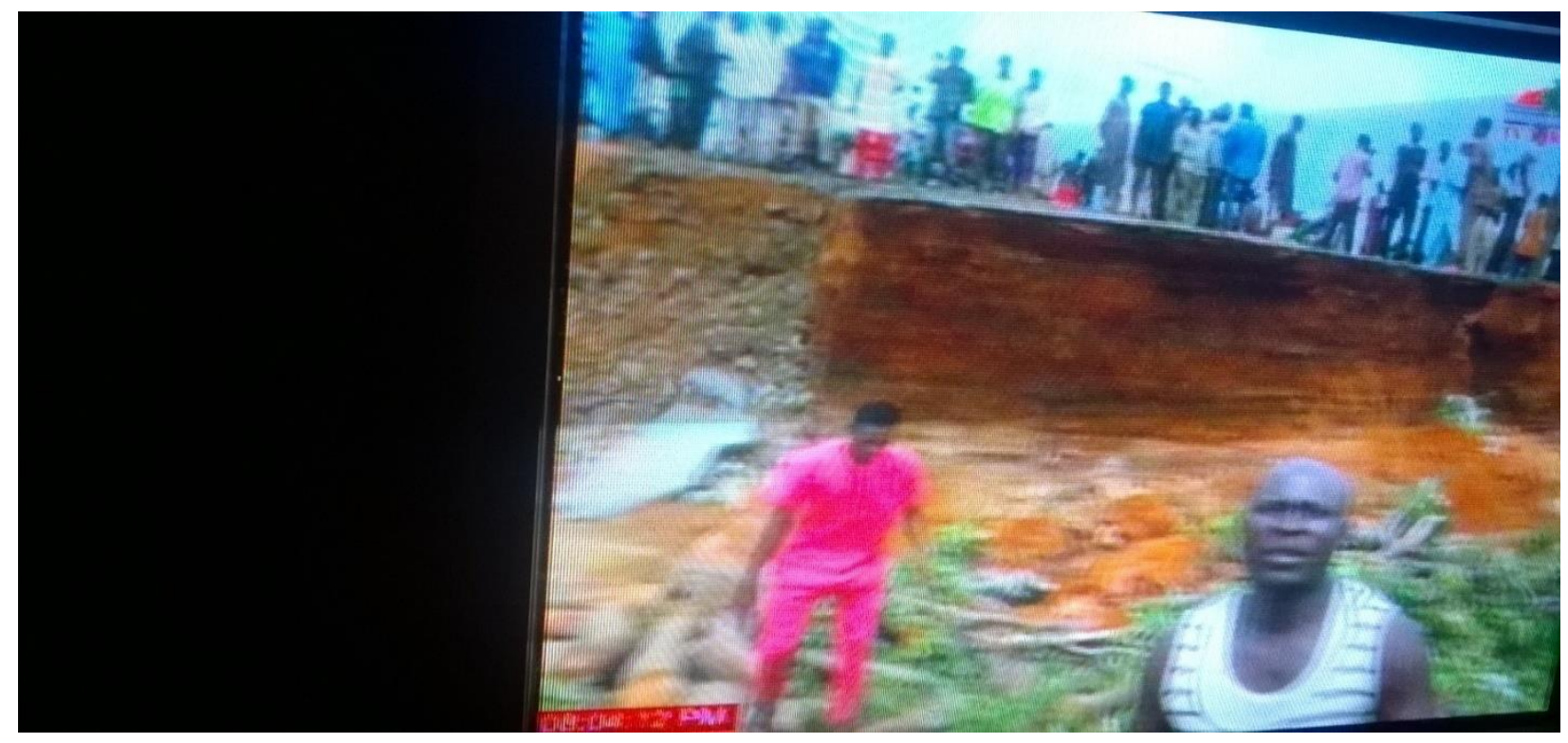

Plate 3: Taraba TV News channel displaying road network disconnection in Jalingo leaving travelers stranded

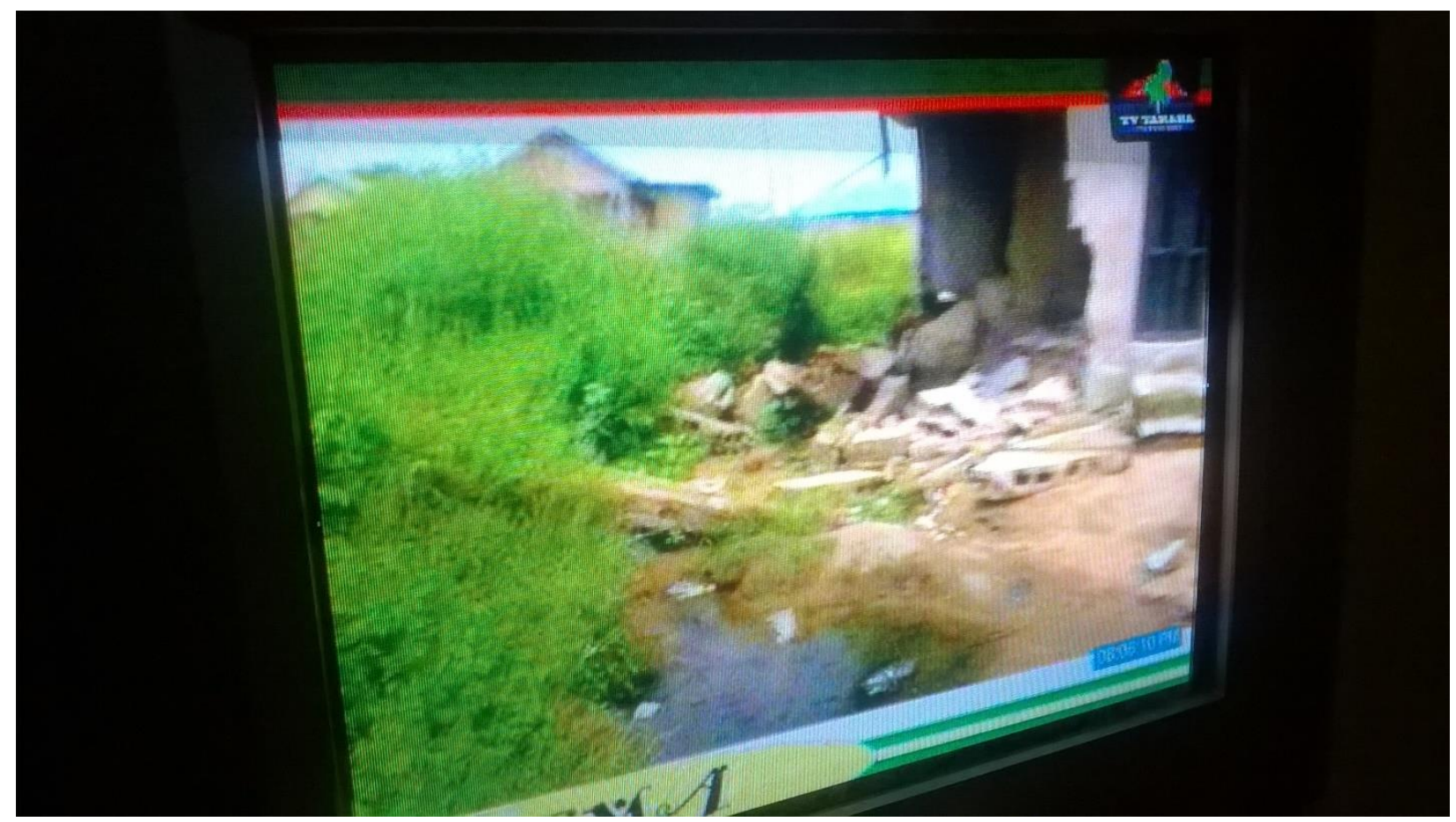

Plate 4: Taraba TV News channel displaying collapsed building along water ways in Fada community 


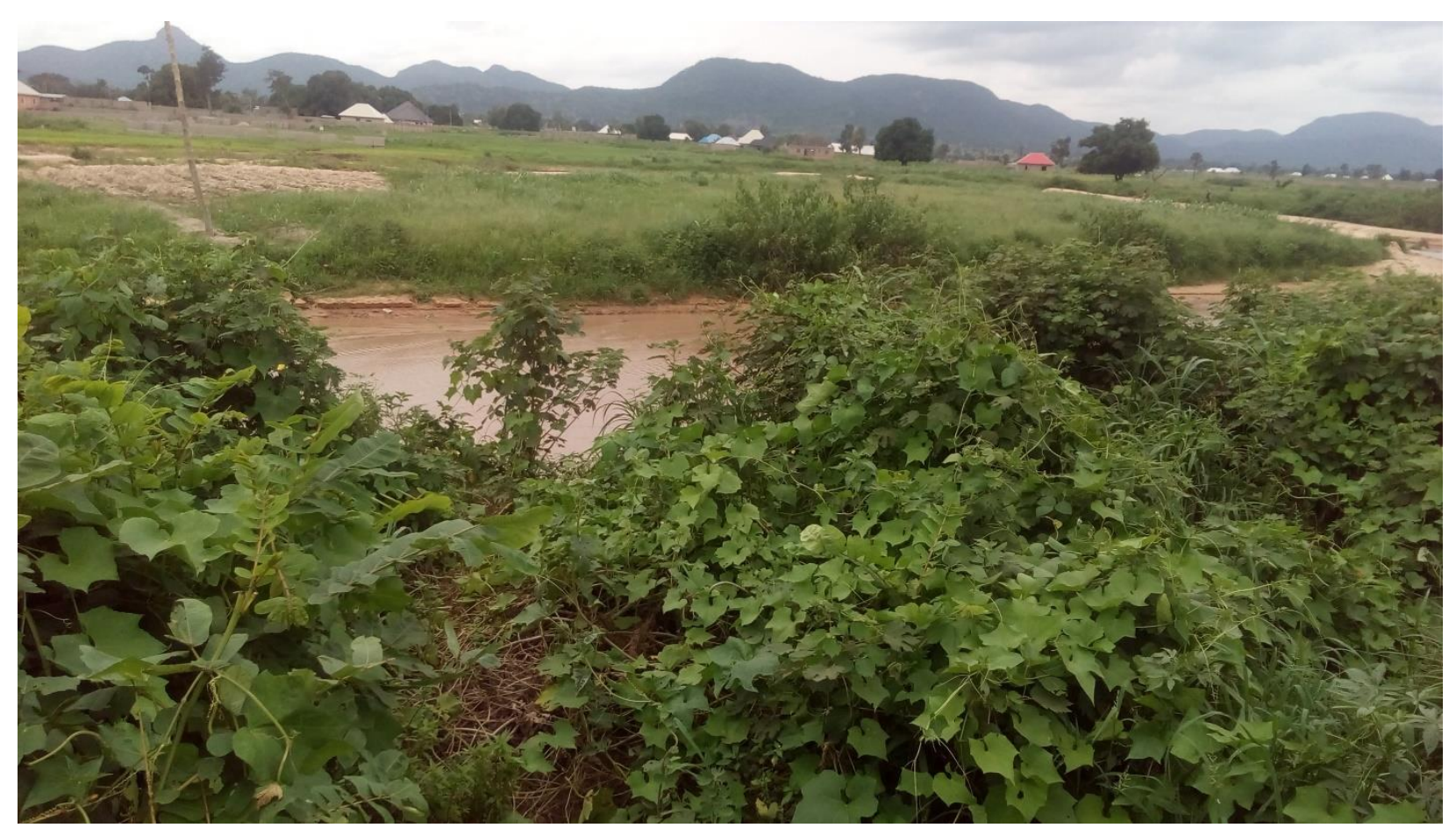

Plate 5: Unlawful settlements along water ways of Lamurde river

\section{AIM AND OBJECTIVES}

The aim of this study was to analyze the spatial and temporal characteristics of the rainfall and categorize the land use type over the study area with a view to determining their influence on flood vulnerability along the major tributaries of River Benue in Taraba State. It evaluates rainfall variability and the influence on runoff (flood) in the state using geospatial and statistical instruments.

\section{STUDY AREA}

The study area lies between latitude $6^{\circ} 30^{\prime}$ and $9^{\circ} 30^{\prime}$ North of equator and between Longitude $9^{\circ} 00^{\prime}$ and $12^{\circ} 00^{\prime}$ East of the Greenwich Meridian. It has a total land area of about $60,291 \mathrm{~km}^{2}$ (National Statistic Office, 2018). The land area has three major tributaries to River Benue: River Lamurde, River Taraba and River Donga (Figure 1). There exist twenty-two sub-basins in the study area and these sub-basins network with these three major rivers and drained a total area of about $44,359 \mathrm{~km}^{2}$ having perimeter of about $1522 \mathrm{~km}$ (Adelalu et al.2020a). Inter-tropical Discontinuity (ITD) determines the climate of the study area which is marked by dry and rainy seasons. Temperature figure typifies African Savanna features (Adebayo and Tukur, 1999) with an average minimum temperature of $15.2^{\circ} \mathrm{C}$, while the average maximum temperature is $39.7^{\circ} \mathrm{C}$. The hottest months are March and April with maxima temperature of $34.5^{\circ} \mathrm{C}$. Rainfall usually starts around April-May and ends around September-October. Heavy thunder storms occur in major parts of the state around July and August. It is not also uncommon to have the peak of rainfall at this period. This may not herald flooding if the system is not reimbursed by water released from Lagdo dam, consequently causing major floods and inundation at about three-quarter of the sixteen local government areas. Crop production, stock raising and animal husbandry form the mainstay of the people. However, 
surge in population especially after the North-east insurgence has been changing the distribution of agricultural land use. Obviously now, farmers are withdrawing from the farmlands to intensive hinterland farming close to houses and drains (Adelalu et al.2020b). This is probably not unconnected with the farmer-pastoralists conflicts in the region. The vegetation type of the study area has been adversely affected by human activities leading to the clearcutting of trees in many parts of the area. Artificial vegetation and few economic trees have replaced the natural vegetation especially as we transverse the northern part of the study area. In the past, the local people usually collect fuel wood right at their backyard but today, they travel a long distance to collect fuel wood for their domestic energy (Oruonye, 2012a).

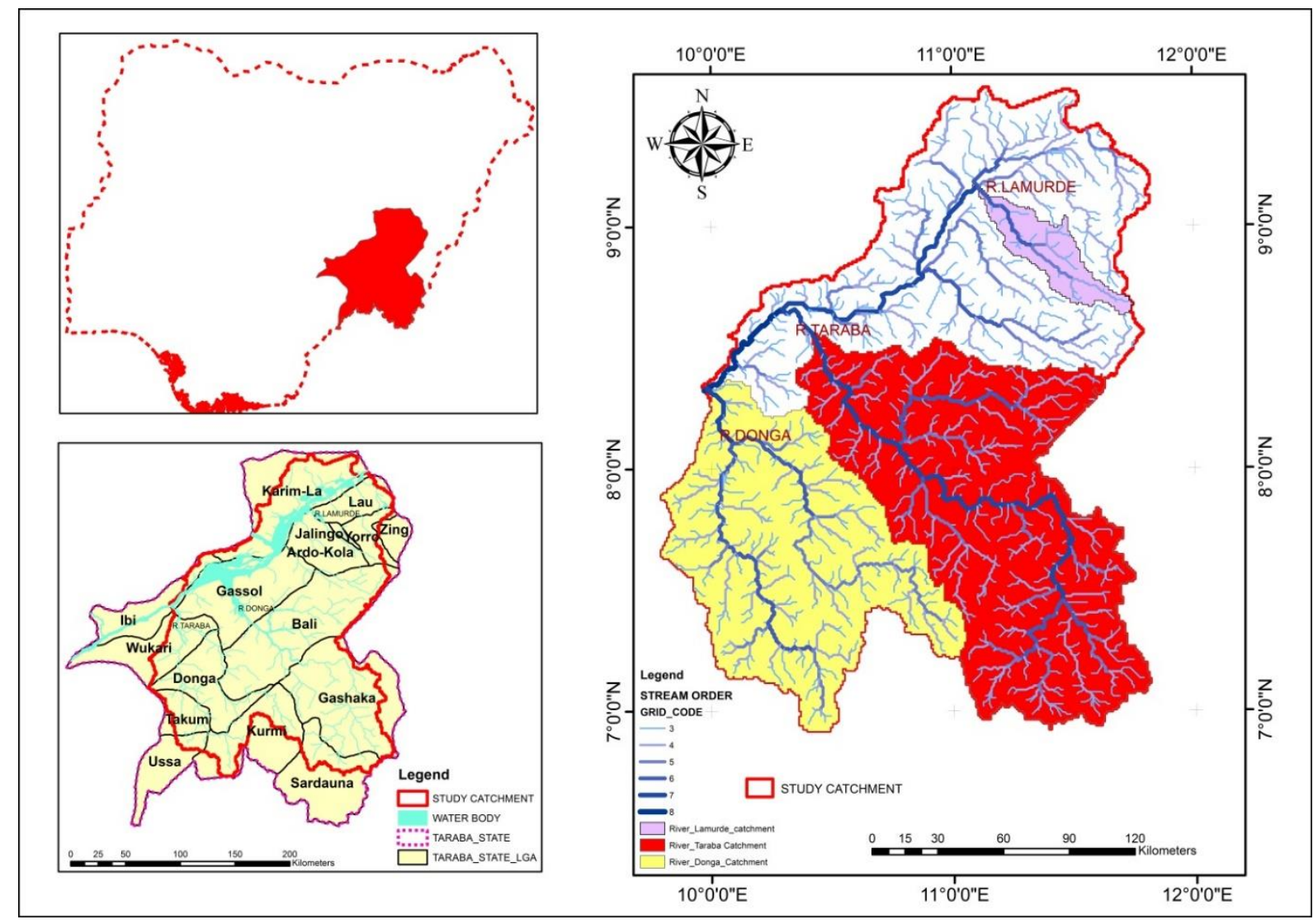

Figure 1: The Study Area showing Drainage Patterns

\section{METHODOLOGY}

The data used for this study include satellite images and the mean annual rainfall and runoff of Taraba. The satellite images of the state were derived from United States Geological Survey Explorer. Image sampling was carried out to determine training sample sets during field checks. For date, source and data format see Table 1. Relationship between rainfall and river flow in Taraba over the years in the study area were determined using thirty-five years of rainfall data. This is available for use in all the study basins except for River Donga, however with adequate hydrological data from stations in three places (Tepkwar, Gindin-Doruwa and Donga). Little data processing was made to augment for missing data in rainfall by using the rainfall simulation of the area downloaded from U.S. 
Geological Survey (USGS) Word Climate Database with the help of ERDAS 9.0 version. The rainfall-runoff relationship of the catchment was established and the rainfall-runoff regression line generated. From this regression equation, fixing of the missing data was made. To determine the land use/land cover type. Training site was chosen to represent land use classes such as vegetation, built up area, bare land and water body. Classifications were limited to these variables because these have been established to have linkage to flooding hazard in the study area. Supervised image classification technique was employed. With this technique, samples of the different features on the image were given pixel depicting a given land use/land cover type. Atmospheric correction was applied to remove the dust and haze effect from the image by using the dark-object subtraction method (Chavez, 2006). The false color composite image was classified using Maximum Likelihood Classification Algorithm. The Maximum Likelihood Classifier assumes that a pixel has certain probability belonging to a particular class. The results from the analysis are presented in the form of tables and map.

Table 1: Data type and source

\begin{tabular}{llllll}
\hline S/N & Type & Catchments & Format & Date & Source \\
\hline 1 & Rainfall & Jalingo & Analogue & $1979-$ & COA/TSU/TARMA \\
& \& Runoff & (R/Lamurde) & & 2018 & \\
& & Gassol & Analogue & $1979-$ & UBRB \\
& & (R/Taraba) & & 2018 & \\
& & Donga & Digital/Analogue & $1979-$ & usgs.worldclim.data/ UBRB \\
& & (R/Donga) & (harmonized) & 2018 & \\
& & & Digital & 2018 & USGS Explorer \\
\hline
\end{tabular}

To assess the inhabitants' level of awareness and cause of flood hazard in the area, questionnaire was designed to capture the bio-data and socioeconomic characteristics of the respondents which include age, sex, marital status, occupation, level of education, and length of stay in the area. The other part of the questionnaire had connection to environmental use and its interrelation with flooding. Purposeful sampling method was used to select sampled wards base on the endemic status of the councils. For instance, Donga has 10 wards but GyataAure and Fada were selected because these two wards were more endemic in times of flooding than any other wards. Similar reason was the bases of selection of wards along river Taraba and river Lamurde. Random sampling was used in the administration of questionnaire and sample size as specified in Table 2.

Table 2: Respondent sampled size distribution by wards in the study area

\begin{tabular}{|c|c|c|c|c|}
\hline Catchment & Wards & Proportion & $\%$ Valid & $\%$ Invalid \\
\hline \multirow[t]{3}{*}{ River Lamurde } & Nukkai & 100 & $241(80.3)$ & $59(19.7)$ \\
\hline & Magami & 100 & & \\
\hline & Kona/ Kogi Muri & 100 & & \\
\hline \multirow[t]{3}{*}{ River Taraba } & Wibo & 100 & $241(80.3)$ & $59(19.7)$ \\
\hline & Natride & 100 & & \\
\hline & Santride & 100 & & \\
\hline \multirow[t]{2}{*}{ River Donga } & Fada & 150 & $131(45)$ & $169(56)$ \\
\hline & Gyata Aure & 150 & & \\
\hline
\end{tabular}




\section{RESULTS AND DISCUSSION}

\section{PRESENT LAND USE PATTERNS IN THE STUDY AREA}

Table 3-5 shows the present land use pattern and percentage proportion in the study area. The three catchments show natural vegetation cover of about 14230 hectares. This account for $50.1 \%$ of the land mass of the catchment area under study. Cultivated area and the bare land amount to about 13146 hectares. This accounts for about $46.3 \%$ of the basin area. Built up area cover of about 806 hectares, occupy just 2.8\%. Owing to the occurrence of good vegetation cover, which is more than $50 \%$ of the basin area, generally one would have expected low occurrence of flooding in the study area however the reverse was the case.

Table 3: Land use types and percentage covered in river Taraba catchment area

\begin{tabular}{lll}
\hline $\begin{array}{l}\text { River Lamurde Catchments } \\
\text { Land use Types }\end{array}$ & Area $\left(\mathbf{k m}^{\mathbf{2}}\right)$ & Percentage\% \\
\hline Vegetation & 567.4 & 44.9 \\
Bare Land & 577.5 & 45.7 \\
Built Up Area & 113.8 & 9.0 \\
Water Body & 5.7 & 0.4 \\
Total & 1264.5 & 100 \\
\hline
\end{tabular}

Source: GIS Analysis, (2018)

Table 4: Land use types and percentage covered in river Taraba catchment area

\begin{tabular}{lll}
\hline $\begin{array}{l}\text { River Taraba Catchments } \\
\text { Land use Types }\end{array}$ & Area $\left(\mathbf{k m}^{2}\right)$ & Percentage \% \\
\hline Vegetation & 8330.3 & 52.8 \\
Bare Land & 6863.0 & 43.5 \\
Built Up Area & 441.8 & 2.8 \\
Water Body & 141.9 & 0.9 \\
Total & 15777.1 & 100 \\
\hline
\end{tabular}

Source: GIS Analysis, (2018)

Table 5: Land use types and percentage covered in Donga catchment area

\begin{tabular}{lll}
\hline $\begin{array}{l}\text { River Donga Catchments } \\
\text { Land use Types }\end{array}$ & Area $\left(\mathbf{k m}^{\mathbf{2}}\right)$ & Percentage $\%$ \\
\hline Vegetation & 5332.2 & 47.0 \\
Bare Land & 5705.7 & 50.2 \\
Built Up Area & 251.4 & 2.2 \\
Water Body & 65.7 & 0.6 \\
Total & 11355.0 & 100 \\
\hline
\end{tabular}

Source: GIS Analysis, (2018)

\section{SPATIAL AND TEMPORAL CHARACTERISTICS OF RAINFALL AND CHANNEL FLOW OVER THE STUDY AREA}

The result from statistical techniques of central tendency and measure of dispersion shows that the highest daily rainfall at Gassol, Donga and Jalingo are $162.0 \mathrm{~mm}, 174.0 \mathrm{~mm}$ and $142.9 \mathrm{~mm}$ respectively and they all occurred in the Month of August. The result also shows that the highest annual rainfall event ever recorded over the period under 
study was in Donga and the least from Gassol. The mean annual rainfall values for Donga, Jalingo, Gassol and Gembu are 2102.2, 1060.9, 1010.1mm respectively (Table VI). Months of August and September were identified as the months with the heaviest rainfall. The maximum annual rainfall ranges from $2198.0 \mathrm{~mm}$ in Donga, $1541.0 \mathrm{in}$ Jalingo, to $1458.3 \mathrm{~mm}$ in Gassol. The rainfall pattern and distribution in the study area is not different from what is generally obtainable in the northeast of Nigeria.

Table 6: Summaries of the results obtained from rainfall data (1979-2018)

\begin{tabular}{|c|c|c|c|c|c|c|c|c|}
\hline & \multirow[t]{2}{*}{ Stations } & \multicolumn{2}{|l|}{ Location } & \multirow[t]{2}{*}{ Mean } & \multirow[t]{2}{*}{ S.D } & \multirow[t]{2}{*}{ Minimum } & \multirow[t]{2}{*}{ Maximum } & \multirow[t]{2}{*}{ CV $(\%)$} \\
\hline & & Long & Lat & & & & & \\
\hline & Jalingo & $8.5^{0} \mathrm{E}$ & $11.1^{0} \mathrm{~N}$ & 1060.9 & 135.8 & 862.0 & 1541.0 & 12.8 \\
\hline$\widehat{\Xi}$ & Gassol & $10.5^{0} \mathrm{E}$ & $8.4^{0} \mathrm{~N}$ & 1010.1 & 177.1 & 674.2 & 1458.3 & 17.5 \\
\hline 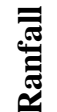 & Donga & $10.0^{0} \mathrm{E}$ & $7.7^{0} \mathrm{~N}$ & 2102.2 & 50.3 & 1935.7 & 2198.0 & 2.3 \\
\hline
\end{tabular}

Table 7: Summaries of the results obtained from channel runoff data (1979-2018)

\begin{tabular}{|c|c|c|c|c|c|c|c|c|}
\hline & Stations & Location & & Mean & S.D & Minimum & Maximum & $\mathrm{CV}$ \\
\hline & & Long & Lat & & & & & $(\%)$ \\
\hline & $\begin{array}{l}\text { Yelwa-Tau } \\
\text { (R/Lamurde) }\end{array}$ & $8.5^{0} \mathrm{E}$ & $11.4^{0} \mathrm{~N}$ & 2504.2 & 359.1 & 1260.5 & 3083.8 & 14.3 \\
\hline$\hat{\Sigma}$ & $\begin{array}{l}\text { Gassol } \\
\text { (R/Taraba) }\end{array}$ & $10.5^{0} \mathrm{E}$ & $8.4^{0} \mathrm{~N}$ & 1331.0 & 6.38 & 1311.0 & 1341.5 & 0.5 \\
\hline 气 & $\begin{array}{l}\text { Donga } \\
\text { (R/Donga) }\end{array}$ & $10.0^{0} \mathrm{E}$ & $7.7^{0} \mathrm{~N}$ & 1123.4 & 3.01 & 1112.9 & 1129.3 & 0.2 \\
\hline
\end{tabular}

\section{RELATIONSHIP BETWEEN RAINFALL AND RIVER FLOW IN TARABA (1979-2018) RAINFALL AND RUNOFF IN RIVER LAMURDE CATCHMENT AREA}

Table 8a gives the correlation matrix of the relationship between rainfall and volume of runoff on river Lamurde catchment. From this table, it is observed that there exist positive relationships, however very low $(r=0.138)$. Pvalue $=0.417$. This suggests that the strength of relationship between the variables is not strong. This implies that an increase in the rainfall causes an increase in runoff flow, but it is probably small and may not be practically significant. Suffice to say that the excess runoff that yearly vortex flooding in many parts of the catchment may not be solidly anchored on the excess rainfall in the study area for the period under consideration. The ANOVA table (Table 8c) shows that $\mathrm{F}=0.675$ is small and $\mathrm{P}$ relatively large $(\mathrm{P}>0.05)$. The $\%$ of variation accounted for by the model $(\mathrm{Y}=932.2+0.01423 \mathrm{X})$, in the ANOVA table is also insignificant. Adjusted R- Square is 0.09 . This means 
the independent variable only account for $0.9 \%$ effect on the dependent variable. This indicates that the predictor (rainfall) does not significantly predict runoff.

Table 8a: Correlation matrix of rainfall - runoff relationship of river Lamurde catchment area

\begin{tabular}{llll}
\hline Correlations & & RUNOFF & RAINFALL \\
\hline \multirow{2}{*}{ Pearson Correlation } & RUNOFF & 1.000 & $.138^{* *}$ \\
& RAINFALL & .138 & 1.000 \\
Sig. (1-tailed) & RUNOFF &. & .208 \\
& RAINFALL & .208 &. \\
N & RUNOFF & 37 & 37 \\
& RAINFALL & 37 & 37 \\
\hline
\end{tabular}

Table 8b: Model Summary

\begin{tabular}{lllll}
\hline Model & R & R Square & $\begin{array}{l}\text { Adjusted R } \\
\text { Square }\end{array}$ & $\begin{array}{l}\text { Std. Error of the } \\
\text { Estimate }\end{array}$ \\
\hline 1 & $.138^{\mathrm{a}}$ & .019 & -.009 & 1298.89014 \\
\hline
\end{tabular}

a. Predictors: (Constant), RAINFALL

b. Dependent Variable: RUNOFF

Table 8c: ANOVA ${ }^{\mathrm{b}}$

\begin{tabular}{lllllll}
\hline \multirow{2}{*}{ Model } & & Sum & of & & \\
& Squares & Df & Mean Square & F & Sig. \\
\hline 1 & Regression & 1138780.172 & 1 & 1138780.172 & .675 & $.417^{\mathrm{a}}$ \\
& Residual & $5.905 \mathrm{E} 7$ & 35 & 1687115.604 & & \\
& Total & $6.019 \mathrm{E} 7$ & 36 & & \\
\hline
\end{tabular}

a. Predictors: (Constant), RAINFALL

b. Dependent Variable: RUNOFF

Table 8d: Coefficients ${ }^{\mathrm{a}}$

\begin{tabular}{|c|c|c|c|c|c|}
\hline \multirow[t]{2}{*}{ Model } & \multicolumn{2}{|c|}{$\begin{array}{l}\text { Unstandardized } \\
\text { coefficient }\end{array}$} & $\begin{array}{l}\text { Standardized } \\
\text { Coefficient }\end{array}$ & $\mathrm{t}$ & Sig. \\
\hline & $B$ & $\begin{array}{l}\text { Std. } \\
\text { Error }\end{array}$ & Beta & & \\
\hline (Constant) & 7605.226 & 1729.338 & & 4.398 & .000 \\
\hline RAINFALL & 1.329 & 1.618 & .138 & .822 & .417 \\
\hline
\end{tabular}

a. Dependent Variable: RUNOFF 


\section{RAINFALL AND RUNOFF IN RIVER TARABA CATCHMENT AREA}

Table 9a gives the correlation matrix of the relationship between rainfall and volume of runoff on river Taraba catchment area. From this table, it is noticed that there exists low strength of correlation $(r=0.224)$. P-value $=$ 0.183. This does not suggest a meaningful strength of association. The ANOVA table shows that $\mathrm{F}=1.845$ is small and $\mathrm{P}>0.05$. The $\%$ of variation accounted for by the model $(\mathrm{Y}=1326+0.0056 \mathrm{X})$, in the ANOVA table is also insignificant. Adjusted R- Square is 0.023 (Table 9b). This means the independent variable only account for $2.3 \%$ effect on the dependent variable. This is the percentage variation in runoff that can be accounted for by the regression model. This indicates that the predictor (rainfall) does not significantly predict runoff.

Table 9a: Correlation matrix of rainfall - runoff relationship of river Taraba catchment area

\begin{tabular}{llll}
\hline Correlations & & RUNOFF & RAINFALL \\
\hline \multirow{2}{*}{ Pearson Correlation } & RUNOFF & 1.000 & .224 \\
& RAINFALL & .224 & 1.000 \\
Sig. (1-tailed) & RUNOFF &. & .092 \\
& RAINFALL & .092 &. \\
$\mathrm{~N}$ & RUNOFF & 37 & 37 \\
& RAINFALL & 37 & 37 \\
\hline
\end{tabular}

Table 9b: Model Summary ${ }^{\mathrm{b}}$

\begin{tabular}{lllll}
\hline Model & $\mathrm{R}$ & $\mathrm{R}$ Square & Adjusted R Square & $\begin{array}{l}\text { Std. Error of the } \\
\text { Estimate }\end{array}$ \\
\hline 1 & $.224^{\mathrm{a}}$ & .050 & .023 & 4.42503 \\
\hline
\end{tabular}

a. Predictors: (Constant), RAINFALL

b. Dependent Variable: RUNOFF

Table 9c: ANOVA ${ }^{\mathrm{b}}$

\begin{tabular}{lllllll}
\hline \multirow{2}{*}{ Model } & & Sum & of & & & \\
& & Squares & Df & Mean Square & F & Sig. \\
\hline 1 & Regression & 36.131 & 1 & 36.131 & 1.845 & $.183^{\text {a }}$ \\
& Residual & 685.331 & 35 & 19.581 & & \\
& Total & 721.462 & 36 & & & \\
\hline
\end{tabular}

a. Predictors: (Constant), RAINFALL

b. Dependent Variable: RUNOFF 
Table 9d: Coefficients ${ }^{\mathrm{a}}$

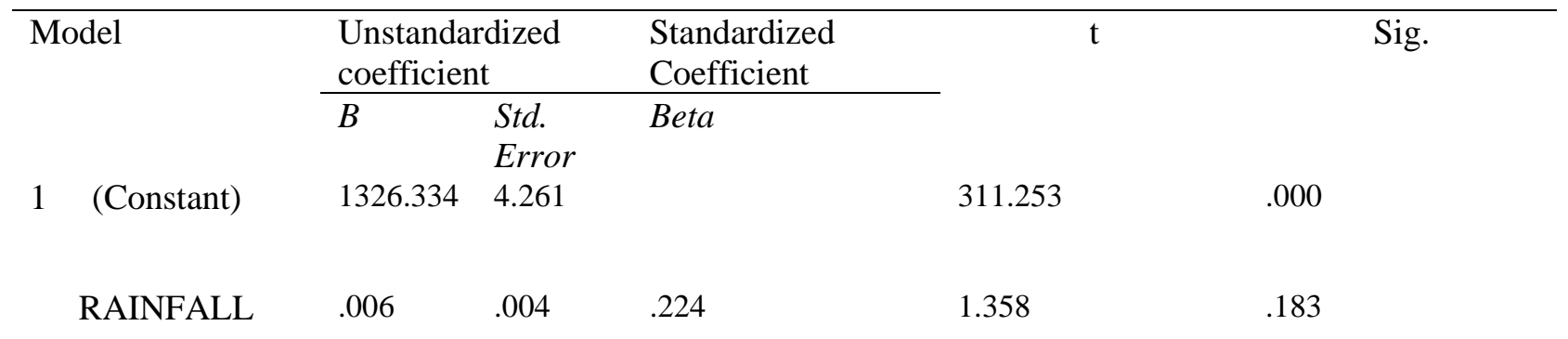

a. Dependent Variable: RUNOFF

\section{RAINFALL AND RUNOFF IN RIVER DONGA CATCHMENT AREA}

Table 10a gives the correlation matrix of the relationship between rainfall and volume of runoff in river Donga catchment area. From the table, it is seen that there exists a strong correlation $(r=0.49)$. The positive correlation indicates that when rainfall increases runoff tends to increase. P-value $=0.002$. This poses a meaningful strength of association. The ANOVA table shows that $\mathrm{F}=10.830$ is large and $\mathrm{P}<0.05$. The $\%$ of variation accounted for by the model is significant. Adjusted R- Square is 0.214 (Table 10b). This means the independent variable only account for $21.4 \%$ effect on the dependent variable. This is the percentage variation in runoff that can be accounted for by the regression model. This is however relatively higher in comparison to the other catchment area. This may not be unconnected to the usage of downloaded data from the internet source to compliment the missing data from that region.

Generally, across the catchment areas, linear regression analysis revealed insignificant relationship between rainfall and runoff. The results do not indicate the rainfall in the region solely contribute to flooding. $\mathrm{R}$ square measures the proportion of the variation in the dependent variable explained by the independent variable in the model. The small values in all the catchments are indication of other factors accounting for large part of the variation in the relationship. Lamurde catchment (.019) Taraba catchment (.050) Donga catchment (.236) indicate that the proportion of variation in dependent variable (runoff) explained by independent (rainfall) are 1.9\%, 5\%, $23.6 \%$ respectively. So, causes of flooding cannot be attributed to rainfall.

Table 10a: Correlation matrix of rainfall - runoff relationship of river Donga

\begin{tabular}{llll}
\hline Correlations & & RUNOFF & RAINFALL \\
\hline \multirow{2}{*}{ Pearson Correlation } & RUNOFF & 1.000 & .486 \\
& RAINFALL & .486 & 1.000 \\
Sig. (1-tailed) & RUNOFF &. & .001 \\
& RAINFALL & .001 &. \\
$\mathrm{~N}$ & RUNOFF & 37 & 37 \\
& RAINFALL & 37 & 37 \\
\hline
\end{tabular}


Table 10b: Model Summary ${ }^{\mathrm{b}}$

\begin{tabular}{|c|c|c|c|c|c|c|}
\hline \multirow{2}{*}{$\begin{array}{l}\text { Model } \\
1\end{array}$} & \multicolumn{2}{|l|}{$\mathrm{R}$} & R Square & \multicolumn{2}{|c|}{ Adjusted R Square } & \multirow{2}{*}{$\begin{array}{l}\text { Std. Error of the } \\
\text { Estimate } \\
1.61531\end{array}$} \\
\hline & $.486^{\mathrm{a}}$ & & .236 & .214 & & \\
\hline \multicolumn{7}{|c|}{ a. Predictors: (Constant), RAINFALL } \\
\hline \multicolumn{7}{|c|}{ b. Dependent Variable: RUNOFF } \\
\hline \multicolumn{7}{|c|}{ Table 10c: ANOVA ${ }^{b}$} \\
\hline & & Sum & of & & & \\
\hline Model & & Squares & Df & Mean Square & $\mathrm{F}$ & Sig. \\
\hline \multirow[t]{3}{*}{1} & Regression & 28.258 & 1 & 28.258 & 10.830 & $.002^{\mathrm{a}}$ \\
\hline & Residual & 91.323 & 35 & 2.609 & & \\
\hline & Total & 119.581 & 36 & & & \\
\hline
\end{tabular}

a. Predictors: (Constant), RAINFALL

b. Dependent Variable: RUNOFF

Table 10d: Coefficients ${ }^{\mathrm{a}}$

\begin{tabular}{|c|c|c|c|c|c|c|}
\hline \multirow{2}{*}{\multicolumn{2}{|c|}{ Model }} & \multicolumn{2}{|c|}{$\begin{array}{l}\text { Unstandardized } \\
\text { coefficient }\end{array}$} & $\begin{array}{l}\text { Standardized } \\
\text { Coefficient }\end{array}$ & \multirow[b]{2}{*}{064127} & \multirow[t]{2}{*}{ Sig. } \\
\hline & & 1085.613 & $\begin{array}{l}\text { Std. } \\
\text { Error } \\
11.258\end{array}$ & Beta & & \\
\hline & RAINFALL & .018 & .005 & .486 & 3.291 & .002 \\
\hline
\end{tabular}

a. Dependent Variable: RUNOFF

\section{COMMUNITIES' ASSESSMENT OF CLIMATE CHANGE: CAUSES AND IMPACT}

The researchers believed that those inhabitants especially long-term residents could have a reasonable idea of the extent of flooding in the locality. The questions in Table X sought to ascertain how long the respondents have lived in the area. For instance, more than $60 \%$ of the respondents in Lamurde had been in the study area for more than 20 years. In river Taraba catchment area, close to $70 \%$ of the respondents had been in the study area for more than 20 years while in Fada and Gyata Aure close to $90 \%$ of the respondents had been in the study area for more than 20 years. It is assumed that they have a better chance of relating the story better.

Regarding the incessant flooding in the Lamurde catchment area, floodplain encroachment and increase in rainfall intensity have been identified as the culprits. Encroachment accounts for $34 \%$ while about $26 \%$ of the respondents support the fact that rainfall intensity increase is the causative agent. Land use change, in the area of increase in deforestation through logging and constructions account for $20 \%$ while about $4 \%$ of the respondents support the fact that the low land terrain is the cause of the flooding. Others factors outside the listed cause in the 
questionnaire identified by respondents include disposal of waste dump in channels and drainages. $16 \%$ of the respondents are in this category (Table 11).

In the lower latitude, at river Taraba catchment area, majority are in the category of other causes different from the listed in the questionnaire. General perception of the respondents who have lived more than 20 years and above in locality affirmed that excess of water from the Lagdo Dam is responsible for the yearly flooding of the area. About $51 \%$ of the respondents are attestants to this (Table 11). Floodplain encroachment accounts for 39\% while about $4 \%$ of the respondents support the fact that the low land terrain is the cause of the flooding. Only $18 \%$ associate increase in rainfall intensity to flooding. Number one on the list on the general perception of the respondents who have lived more than 20 years and above in Fada and Gyata Aure localities affirmed that there has been increase in the rainfall intensity. About $47 \%$ of the respondents are attestants to this (Table 11). This corroborates the findings of Oyatayo et al., 2015. However, up north of the study area, in Lamurde and Taraba basin, according to preliminary report (Adebayo, 2012), rainfall have been decreasing.

Also, in Fada and Gyata Aure floodplain encroachment accounts for $37 \%$ while about $8 \%$ of the respondents support the fact that the low land terrain is the cause of the flooding. Even though only $8 \%$ of the respondents adduced flooding to change in land use and land cover, the analyzed imageries by (Gabriel and Audu, 2017) show that between the spaces of 16 years, (2000-1016) the present built up area is fifth times of the capture in the year 2000 and that $16 \%$ of the vegetation cover has disappeared for other use.

The responses in Table 12 indicated flood impact on the populace of Jalingo community in the past along river Lamurde. $9 \%$ are attestant to the fact that they had directly lost farm land or they know somebody in the area who loss farm land to flooding. 128 respondents confirm reduction in farm yield as a result of farm flush or overflow account for about 53\%. Other areas of effect as depicted by the respondents include; destruction of properties/ Infrastructures, hike in food crops, Increase erosion, loss of family member etc. Populace of Gassol community, in the past along river Taraba, indicated that loss of farm land dominates the effect of past flood on the populace. $85 \%$ are attestant to the fact that they had directly lost farm land or they know somebody in the area who loss farm land to flooding. 199 respondents confirm reduction in farm yield as a result of farm flush or overflow account for about $82 \%$. Other areas of effect as depicted by the respondents include; destruction of properties/ Infrastructures, hike in food crops, Increase erosion etc. In the lower latitude, 92 of the respondents indicated loss of farm land as their share of effect of past flood in Donga. 118 respondents confirm reduction in farm yield as a result of farm flush or overflow accounting for about $90 \%$ of the populace. Other areas of effect as depicted by the respondents include; destruction of properties/ Infrastructures, hike in food crops, Increase erosion etc. (Table 12). 
Table 11: Perceived causes of incessant flooding in study area

\begin{tabular}{|c|c|c|c|}
\hline \multirow{9}{*}{ 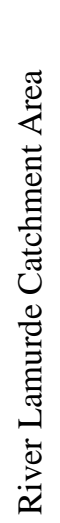 } & Variables (causes) & Frequency & Percentage $(\%)$ \\
\hline & Floodplain Encroachment & 81 & 34 \\
\hline & Increase Rainfall intensity & 63 & 26 \\
\hline & Land use change( & 49 & 20 \\
\hline & Deforestation, Constructions & & \\
\hline & etc) & & \\
\hline & Low land area & 9 & 4 \\
\hline & Others & 39 & 16 \\
\hline & Total & 241 & 100 \\
\hline \multirow{9}{*}{ 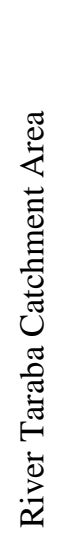 } & Variables (causes) & Frequency & Percentage $(\%)$ \\
\hline & Floodplain Encroachment & 39 & 16 \\
\hline & Increase Rainfall intensity & 44 & 18 \\
\hline & Land use change( & 26 & 11 \\
\hline & Deforestation, Constructions & & \\
\hline & etc) & & \\
\hline & Low land area & 10 & 4 \\
\hline & Others & 122 & 51 \\
\hline & Total & 241 & 100 \\
\hline \multirow{8}{*}{ 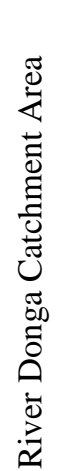 } & Variables (causes) & Frequency & Percentage $(\%)$ \\
\hline & Floodplain Encroachment & 49 & 37.4 \\
\hline & Increase Rainfall intensity & 61 & 46.6 \\
\hline & Land use change( & 11 & 8.4 \\
\hline & Deforestation, Constructions & & \\
\hline & etc) & & \\
\hline & Low land area & 10 & 7.6 \\
\hline & Total & 131 & 100 \\
\hline
\end{tabular}

Source: Field survey, 2018 
Table 12: Flood impact on the populace in the past along river catchments under study

\begin{tabular}{|c|c|c|c|}
\hline \multirow{12}{*}{ 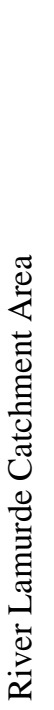 } & Adverse Effects & Frequency & $\%$ \\
\hline & Loss of farm Land & 22 & 9 \\
\hline & Reduced Harvest & 128 & 53 \\
\hline & Hike in food crops & 113 & 47 \\
\hline & Destruction of Properties/ Infrastructures & 82 & 34 \\
\hline & Increase erosion & 71 & 29 \\
\hline & Water Born Diseases & 99 & 41 \\
\hline & Water Pollution & 1 & 0.4 \\
\hline & Albeit Social Vices & 54 & 22 \\
\hline & Temporal Famish & 6 & 2 \\
\hline & Pressure on Land & 61 & 25 \\
\hline & Death/Loss of relative/friends & 1 & 0.4 \\
\hline \multirow{12}{*}{ 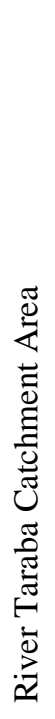 } & Adverse Effects & Frequency & $\%$ \\
\hline & Loss of farm Land & 206 & 85 \\
\hline & Reduced Harvest & 199 & 82 \\
\hline & Hike in food crops & 41 & 17 \\
\hline & Destruction of Properties/ Infrastructures & 72 & 30 \\
\hline & Increase erosion & 79 & 33 \\
\hline & Water Born Diseases & 101 & 42 \\
\hline & Water Pollution & 16 & 7 \\
\hline & Albeit Social Vices & 36 & 15 \\
\hline & Temporal Famish & 66 & 27 \\
\hline & Pressure on Land & 6 & 2 \\
\hline & Death/Loss of relative/friends & - & - \\
\hline \multirow{12}{*}{ 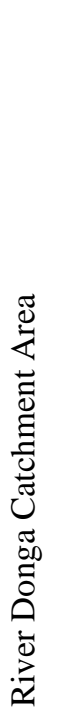 } & Adverse Effects & Frequency & $\%$ \\
\hline & Loss of farm Land & 92 & 70 \\
\hline & Reduced Harvest & 118 & 90 \\
\hline & Hike in food crops & 101 & 77 \\
\hline & Destruction of Properties/ Infrastructures & 62 & 47 \\
\hline & Increase erosion & 79 & 60 \\
\hline & Water Born Diseases & 61 & 47 \\
\hline & Water Pollution & 5 & 4 \\
\hline & Albeit Social Vices & 12 & 9 \\
\hline & Temporal Famish & 3 & 2 \\
\hline & Pressure on Land & 31 & 24 \\
\hline & Death/Loss of relative/friends & 0 & 0 \\
\hline
\end{tabular}

Source: Field survey, 2018 


\section{CONCLUSION}

This work has demonstrated the existence of climate change in Taraba state especially along the major tributaries of river Benue in the state. The local farmers are aware of the changes in environment and their assessments conformed the scientific analysis. Generally, across the catchment areas, linear regression analysis revealed insignificant relationship between rainfall and runoff. The results do not indicate that rainfall in the region solely contribute to flooding. The small values of $\mathrm{R}$ square in all the catchments are indication of other factors accounting for a larger part of the variation in the relationship. Lamurde catchment (.019) Taraba catchment (.050) Donga catchment (.236) indicate that the proportion of variation in dependent variable (runoff) explained by independent (rainfall) are 1.9\%, $5 \%, 23.6 \%$ respectively. Therefore, causes of flooding cannot be solely attributed to rainfall. Though, climate change alters our physical veracities, the problem of yearly flooding is more a human than a natural one in Taraba State. Various anthropogenic activities such as agriculture, deforestation, irrigations, dam construction have taken place especially along the river banks of the major tributaries to river Benue in the state. The cumulative effect of these human activities (deforestation, encroachment, artisan mining etc.) together with natural factors in some parts of the study area has led to environmental degradation in the state which seems abetting incessant flooding.

\section{RECOMMENDATIONS}

The region's status is vulnerable to climate change no doubt. However, the vulnerability has alliance with the Land use and land cover change. The present government effort in the channelization of the drainage is commendable. There is need for farmers to adopt 'farm forest' method of farming system, holistic logging and infrastructural development by respective stakeholders. Farm forest will not only checkmate adverse effect of flooding but serve as windbreak and source of additional revenue apart from adding nutrients to the soil. Tree planting campaign and implementation in the state by some concerned NGO was not sustained in the state. Many trees that were planted were eaten up by goats or dried up by scorching radiation of the sun. Nonchalant attitude of officers designated in some government areas and house landlords' responsibilities to monitor and provide water for the trees planted to their frontage need to be addressed. There is need for a platform e.g. office of Climate Change and Land Reform and the office should be saddled with the responsibility to disseminate and also to create more awareness on climate change, danger of flood plain encroachment.

\section{CONFLICT OF INTEREST}

The authors declare that we have no conflict of interest as authors.

\section{ACKNOWLEDGEMENT}

The authors acknowledge the assistance rendered by the ministry of Upper Benue River Basin Development Authority, UBRBDA,Yola and the Geography Department of Taraba State University, for the provision of all necessary data for the success of this research. 


\section{REFERENCES}

Adebayo, A.A. (2012). Evidence of Climate change in Taraba State: A Preliminary Report. Paper presented at the Faculty of science Seminar Series, held at the lecture hall on $13^{\text {th }}$ September 2012. Taraba State University, Jalingo, Nigeria.

Adebayo, A.A., \& Orunoye, E.D. (2013). An Assessment of Climate Change in Taraba State, Nigeria. Nigerian Journal of Tropical Geography, 4(2): 11-15

Adebayo, A. A., \& Tukur A.L. (1999): Adamawa in maps. Department of Geography. Futy. Adamawa State, Nigeria. Paraclete Publishers \& Sons Yola.1(2): 17-19.

Adelalu, T. G, Ibrahim, A., Ezekiel, B. B, \& Clement, Y.G. (2020a). Comparative Morphometric Analysis of the Major Tributaries of River Benue in Taraba State using Geospatial Techniques. London Journal of Research in Humanities and Social Sciences, 20 (2) Compilation 1.0:11-24.

Adelalu, T. G, Mohammed B.Y, Ezekiel, B. B, \& Clement, Y.G. (2020b) Sorghum Forage Farming for Crisis Resolution and Food Security in a Changing World: A Preliminary Study of Taraba State Nigeria Sorghum Production, Prospects and Problems. International Journal of Environment and Climate Change, 10(8): 46-57.

Chavez, P.Z. (2006). Image-based atmospheric correction: revised and improved. Photogrammetric Engineering and Remote Sensing, 62(6):1052-1036

Elena,,C. Marie, T.V and Nick, V.G.(2017). Spatial and temporal variability of rainfall and their effects on hydrological response in urban areas-a review. Journal of hydrology and Earth system sciences. 21(5): 3859-3878.

Gabriel, A.T and Audu, Z.A (2017). Land Use and Implication on Natural Environment of Donga LGA, Nigeria. Physical Science International Journal 16(4): 1-10, Article no. PSIJ.37098. DOI: 10.9834/PSIJ/2017/37098

IMF, (1993). International Monetary Fund Survey, June, 1993, P187.

McKenzie, F. C and Williams, J. (2015). Sustainable food production: constraints, challenges and choices by 2050. Springer Science. 6(4): 1-13.DOI 10.1007/s12571-015-0441-1.

Oruonye, E.D. (2011). Socio-Economic Impact Assessment of Flash Flood in Jalingo Metropolis, Taraba State, Nigeria. International Journal of Environmental Sciences. 1 (3).135-140.

Oruonye, E.D. (2012a). Socio-Economic Impact assessment of Flash Flood in Jalingo Metropolis, Taraba state Nigeria. International Journal of Environmental Sciences. 1 (3) 135-140.

Oyatayo, K.T., Songu, G.A., Adi, T.A., Abuh, P.O., \& Ndabula, C. (2015). Assessment of people's awareness and perception of flooding in Donga Town, Taraba state, Nigeria. International Conference \& Annual General Meeting of the Nigerian Meteorological Society held on $23^{\text {rd }}-26^{\text {th }}$ Sokoto, Nigeria. 
Parvin, E, Elaheh, F., \& Mehrangiz, E.M. (2019). Household Food Security status and its associated factor in Baftkerman, IRAN: a cross-sectional study.Journal of Ecology of Food and Nutrition.58( 6): 608-619. DOi.org/10.1080/03670244.2019.1652818

Predrag, P., \& Slobodan, P. (2007). Development of rainfall intensity duration frequency curves for the City of London under the changing climate. Water Resources Research Report. Report No: 058:50

Upper Benue River Basin Development Authority, UBRBDA.(1979 - 2018). Hydro meteorological Year Book Yola, Nigeria. 